\title{
Measuring production of continuously grazed hill pastures
}

\author{
B.P. DEVANTIER ${ }^{1}$, M.G. LAMBERT ${ }^{1}$, I.M. BROOKES ${ }^{2}$ and C.L. HAWKINS ${ }^{1}$ \\ ${ }^{1}$ AgResearch, Grasslands Research Centre, PB 11008, Palmerston North \\ ${ }^{2}$ Institute of Food, Nutrition and Human Health, Massey University, Palmerston North
}

\begin{abstract}
Estimates of pasture production are critical for comparing treatment effects in research trials, as inputs to decision support models, and for on-farm use in constructing grazing plans. We compared two techniques for measuring pasture production, over 2 years in 36 paddocks continuously grazed with sheep, on hill country at the Ballantrae Research Station. One technique (Cut method) involved harvesting pasture regrowth after trimming to a standard height. The other (Model method) calculated pasture production as the sum of grazing animal intake (estimated using a spreadsheet-based model with inputs including animal performance and pasture quality) and changes in pasture cover (above-ground biomass). Annual pasture production estimates were reasonably well correlated $\left(\mathrm{R}^{2}=0.66\right)$, but those using the Cut method were 55\% greater than using the Model method. Agreement was best in spring and summer, and poorest in autumn and winter. Factors contributing to these discrepancies included the contrasting starting conditions for the pasture at the start of each measurement period (shorttrimmed for the Cut method, and patch-grazed for the Model method); the effect of grazing in the Model method maintaining pastures in a more vegetative state; and the greater losses from senescence and decay in the Model method pastures. The potential for errors using the Model method was high where measurement periods were short, as accuracy of measurement of pasture cover can be suspect. The Model method probably better quantified net pasture production in grazed pastures.
\end{abstract}

Keywords: grazing, hill pasture, intake, model, pasture production

\section{Introduction}

Estimates of pasture production are critical for assessment of treatment effects in research trials, for use as inputs to decision support models, and for onfarm use in constructing grazing plans. The techniques most commonly used to estimate pasture production under continuous grazing in New Zealand have revolved around harvesting of herbage, which is protected from grazing animals and accumulates on a defined plot area over a period of time. Such approaches introduce artificiality into the assessment, and previous studies have suggested that the actual rates of net pasture production occurring in grazed pastures are substantially different from those estimated using harvested plot techniques (Field et al. 1981; Parsons et al. 1984; Laidlaw et al. 1994; Piggot 1997).

In a pasture protected from defoliation, net pasture production (NPP) is equal to the rate of change in pasture cover (CC) or above-ground biomass, and represents the balance between appearance of new tissue (G) and disappearance of senescent tissue (D), i.e., NPP $=\mathrm{G}-\mathrm{D}=\mathrm{CC}$. Hence NPP can be increased by decreasing the amount of material dying and decomposing. For continuously stocked pastures, the rate of change in pasture cover is also affected by consumption by grazing animals (A), so NPP $=\mathrm{CC}+\mathrm{A}$.

In this paper we present results from a comparison of pasture production measurement methods made using a popular harvested-plot technique based on measurement of cover changes (regrowth) on trimmed plots protected from grazing, and an alternative approach involving estimation of grazing animal herbage intake and measurement of pasture cover changes within the grazed paddock.

\section{Methods}

Measurements were made over 2 years, 1993/94 (Year 1) and 1994/95 (Year 2), within a grazing trial on hill country at AgResearch's Ballantrae Research Station in southern Hawke's Bay. This trial had 4 fertiliser application treatments, and as a result of the effects of differential superphosphate application on pasture production during 1975-93, stocking rates in these treatments had averaged 8.3 to $14.8 \mathrm{su} / \mathrm{ha}$. Other pasture characteristics also varied widely as a result of the historical treatments. Each treatment had 8-10 paddocks of area $0.5-1.1 \mathrm{ha}$, and the 36 paddocks were individually stocked with Romney ewes in a put-andtake system designed to maintain pasture cover at $<2500$ kg dry matter (DM)/ha (Lambert et al. 1996). 
Pasture production was measured directly using a technique (the "Cut method"), whereby herbage was harvested from within three $1.0 \times 0.5 \mathrm{~m}$ grazing exclosure cages per paddock. These cages were placed over trimmed (10 $\mathrm{mm}$ height) pasture, and the accumulated herbage harvested to the same height after an average (longer during slow growth, shorter during rapid growth) regrowth period of 7.5 weeks, i.e., 7 times per year. Harvested herbage was dried and weighed, and values for each paddock averaged for each regrowth period. Cages were sited on the average paddock slope, and were moved to a new adjacent site of the same slope for each harvest period.

Pasture production was also estimated indirectly (the "Model method") for the same periods as used for the Cut method. With the Model method, net pasture production was calculated as the sum of estimated pasture intake by grazing livestock, plus change in pasture cover from the start to the end of the period. Intake was estimated using a spreadsheet-based model (Brookes et al. 1993) which calculated daily DM intake from published equations for energy requirement. Input data, collected over the 2-year period, were livestock numbers, ewe and lamb liveweights, mating and lambing date, lambing \%, wool production and shearing date, and feed energy concentration. Because of the put-andtake system used, there were "tester" animals (breeding ewes) in each paddock throughout the year, and a variable number of dry "grazers" present during the November to February period. Pasture cover was measured 3- to 4-weekly, by taking 30 measurements per paddock using a calibrated rising plate meter. Calibration cuts to ground level were made across the existing pasture cover range every 6 weeks, and a "moving average" regression of cover against plate reading calculated using data from the last, present and next calibration cuts.

Seasonal (3-month seasons, spring starting in September) and annual pasture production estimates made by the two methods were compared using analysis of variance, with method and fertiliser treatment as main effects, and paddocks treated as replicates within fertiliser treatment. Relationships between the methods were explored by linear regression analysis.

\section{Results and discussion}

Pasture production estimates made using the Cut method were significantly higher $(\mathrm{P}<0.001)$ than those of the Model method, for all seasonal and annual totals (Table 1). Annual production estimates were on average $55 \%$ greater using the Cut method; and values for spring and summer were consistently greater by an average $32 \%$ and $34 \%$, respectively. Differences between the two methods were even greater for autumn (Cut method on average $75 \%$ greater) and winter (on average $714 \%$ greater), but were inconsistent across the two seasons and years (Table 1). This result is similar to that obtained by Piggot (1997) for dairy pastures, the Cut method giving annual pasture production values $30 \%$ greater than a "whole farm" technique which directly estimated changes in pasture cover and animal intake.

Table 1 Estimates of seasonal and annual net pasture production (kg DM/ha) using Cut and Model methods, for 2 years and 4 seasons.

\begin{tabular}{lcccc}
\hline Season & Year & $\begin{array}{c}\text { Cut } \\
\text { Method }\end{array}$ & $\begin{array}{c}\text { Model } \\
\text { Method }\end{array}$ & $\begin{array}{c}\text { Ratio } \\
\text { Cut:Model }\end{array}$ \\
\hline Annual & 1 & 10120 & 6190 & 1.63 \\
& 2 & 9900 & 6680 & 1.48 \\
Spring & 1 & 3520 & 2570 & 1.37 \\
& 2 & 3320 & 2520 & 1.32 \\
Summer & 1 & 3730 & 2820 & 1.32 \\
& 2 & 3110 & 2380 & 1.31 \\
Autumn & 1 & 1630 & 1130 & 1.44 \\
& 2 & 2420 & 1050 & 2.30 \\
Winter & 1 & 1240 & -320 & $\mathrm{nc}$ \\
& 2 & 1050 & 590 & 1.78 \\
\hline
\end{tabular}

nc not calculated

The greater estimates for the Cut compared with the Model method probably occurred because that technique involved measurement of regrowth from a short trimmed sward which was growing at near-maximum rates throughout the regrowth period, i.e., this represented the potential growth rate for the prevailing environmental conditions. In contrast, the Model technique estimated production from pastures which, although maintained on average at $<2500 \mathrm{~kg} \mathrm{DM} / \mathrm{ha}$ pasture cover, in fact exhibited within any paddock a wide range of covers because of the patch-grazing behaviour of sheep. Hence a considerable area of the pasture in each paddock would have had covers greater than the maximum of the optimum range for pasture growth of 1000 to $2500 \mathrm{~kg}$ DM/ha (Bircham \& Hodgson 1983) during the warmer parts of the year, and growing at a rate below its potential. Also, defoliation of grass reproductive tillers during spring and early summer would maintain the grazed pasture in a more-vegetative state than the pasture under the grazing exclosures, leading to a lowered growth potential. In addition, accumulation of dead matter in the pasture would have been minimised through the trimming which occurred at the start of each measurement period in the Cut method. As pointed out in the Introduction, decreasing dead matter appearance rate increases net pasture production. With the Model method, covers in the grazed pasture would have been 
higher at the start of most measurement periods, compared with the pasture trimmed to a $10 \mathrm{~mm}$ standard height for the Cut method, and losses to death and decay generally increase with pasture cover (Grant $e t$ al. 1983); in addition herbage would have been older, also leading to higher losses.

The relationships between Cut estimates and Model estimates were strongest for annual and spring pasture production, intermediate for summer and autumn, and very weak for winter (Table 2).

Table 2 Regressions equations describing relationships between Cut method estimates of pasture production and Model method estimates (annual and seasonal equations for 2 years).

\begin{tabular}{lclc}
\hline Season & Year & \multicolumn{1}{c}{ Equation } & $\mathrm{R}^{2}$ \\
\hline Annual & 1 & Cut $=1338+(1.41 \times$ Model $)$ & 0.66 \\
& 2 & Cut $=2403+(1.12 \times$ Model $)$ & 0.66 \\
Spring & 1 & Cut $=-29+(1.38 \times$ Model $)$ & 0.72 \\
& 2 & Cut $=1212+(0.83 \times$ Model $)$ & 0.61 \\
Summer & 1 & Cut $=-53+(1.34 \times$ Model $)$ & 0.50 \\
& 2 & Cut $=-28+(1.32 \times$ Model $)$ & 0.55 \\
Autumn & 1 & Cut $=848+(0.68 \times$ Model $)$ & 0.15 \\
& 2 & Cut $=1357+(0.89 \times$ Model $)$ & 0.42 \\
Winter & 1 & Cut $=1461+(0.68 \times$ Model $)$ & 0.15 \\
& 2 & Cut $=850+(0.34 \times$ Model $)$ & 0.06 \\
\hline
\end{tabular}

Change in pasture cover from start to end of the measurement period was very small (average $50 \mathrm{~kg}$ $\mathrm{DM} / \mathrm{ha}$ ) for annual pasture production estimates, and would have had little influence on predicted pasture production using the Model method, i.e., in that case $\mathrm{NPP} \approx$ Intake. This has practical implications for farmers, as this means (within realistic boundaries) that net pasture production increases as stocking rate, and utilisation/consumption of pasture, increases. Well-utilised pastures also generally have higher nutritional value, because of lower dead matter and stem content, and higher green leaf content. This may explains why profitability of sheep and beef farms is associated with relatively high stocking rates and per animal performance (Taylor \& McRae 1977; Davison 1991), i.e., because net pasture production and pasture quality are higher on such properties.

Cover change was also small in autumn relative to animal intake (Figure 1), but was more influential in spring and summer. In winter, pasture cover change was negative (Figure 1) and almost of the same magnitude as estimated intake (-780 cf. $910 \mathrm{~kg} \mathrm{DM} / \mathrm{ha}$ ). Because of higher pasture covers during summer and autumn, and because grazing animals discriminated strongly against it (Clark et al. 1982), dead matter accumulated in the pasture over those seasons. The large drop in pasture cover during winter would have been a result of decay of this material, leading to very low winter production estimates using the Model method.

Accurate measurement of pasture cover was difficult, particularly with regard to calibration of the rising plate. Where changing pasture cover has a significant effect on the Model estimates, and particularly over short time periods, particular attention needs to be paid to this source of error. It is possible that green pasture production estimates using the two methods would be more closely related than the tot pasture production used here, as the complications caused by dead matter accumulation/disappearance, particularly in the grazed pasture, would be avoided.

The Cut method has been widely used, and where relative pasture production differences between paddocks or experimental treatments is of interest then the method serves a valuable purpose. The greatest concurrence between methods will occur where the grazing system most closely resembles the defoliation regime (intensity/frequency) used for the Cut method (Lambert et al. 1983). However present grazing systems, particularly those where mechanical conservation of pasture is not an option, would be unlikely to maintain all pastures on a farm at near-maximum growth rates throughout the year. The current move to higher lambing percentages coupled with later lambing, should help maintain grazing pressure through the spring and effectively increase net pasture production.

Figure 1 Magnitude of Cut and Model method estimates of average seasonal pasture production, and of estimates of animal intake and pasture cover change (kg DM/ha/season)

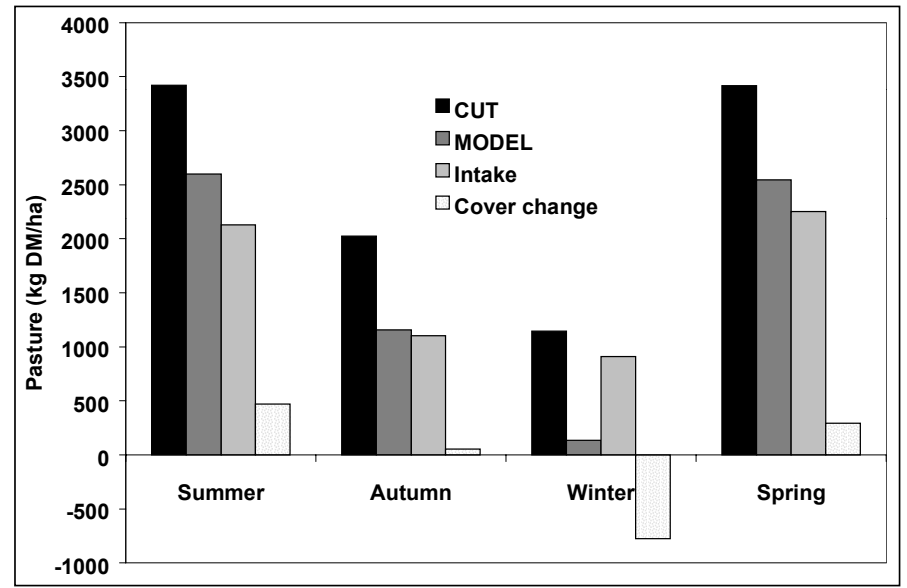


Where accurate estimates of production from grazed pasture are necessary, e.g., for feed budgeting purposes, the Cut method will in many instances over-estimate actual net herbage production. In such situations, published results from trials using plot-harvesting techniques should be treated with caution.

\section{REFERENCES}

Bircham, J.S.; Hodgson, J. 1983. The influence of sward conditions on rates of herbage growth and senescence in mixed swards under continuous stocking management. Grass and forage science 38: $323-$ 331.

Brookes, I.M.; Morris, S.T.; Parker, W.J. 1993. Computer spreadsheets for predicting feed requirements and feed budgeting. Proceedings of the New Zealand Grassland Association 55: 209-210.

Clark, D.A.; Lambert, M.G.; Chapman, D.F. 1982. Pasture management and hill country production. Proceedings of the New Zealand Grassland Association 43: 205-214.

Davison, R.M. 1991. A review of financial and production trends in the New Zealand sheep and beef sector. Paper No. G2026, New Zealand Meat \& Wool Board's Economic Service.

Field, T.R.O.; Clark, D.A.; Lambert, M.G. 1981. Modelling a hill country sheep production system. Proceedings of the New Zealand Society of Animal Production 41: 90-94.

Grant, S.A.; Barthram, G.T.; King, J.; Smith, K. 1983. Sward management, lamina turnover, and tiller population density in continuously stocked Lolium perenne dominated swards. Grass and forage science 38: 333-344.

Laidlaw, A.S.; Withers, J.A.; Watson, S. 1994. Estimating errors in calculating herbage growth from net herbage accumulation rates in continuously stocked swards. Grasslands and Society. Proceedings of the $15^{\text {th }}$ General Meeting of the European Grassland Federation: 181-184.

Lambert, M.G.; Clark, D.A.; Grant, D.A.; Costall, D.A.; Fletcher, R.W. 1983. Influence of fertiliser and grazing management on North Island hill country. 1. Herbage accumulation. New Zealand journal of agricultural research 26: 95-108.

Lambert, M.G.; Barker, D.J.; Mackay, A.D.; Springett, J. 1996. Biophysical indicators of sustainability of North Island hill pasture systems. Proceedings of the New Zealand Grassland Association 57: 3136.

Parsons, A.J.; Collett, B.; Lewis, J. 1984. Changes in the structure and physiology of a perennial ryegrass sward when released from a continuous stocking management: implications for the use of exclusion cages in continuously stocked swards. Grass and forage science 39: 1-9.

Piggot, G. 1997. Pasture production of northern dairy farms. Proceedings of the New Zealand Grassland Association 59: 103-106.

Taylor, N.W.; McRae, A.F. 1977. The effect of increased farm production on profitability and workload. Proceedings of the Ruakura Farmers' Conference: 75-79. 